\title{
Lentinus crinitus RESPONSE TO BLUE LIGHT ON CARBOHYDRATE- ACTIVE ENZYMES
}

\author{
EFEITO DA LUZ AZUL NA PRODUÇÃO DE ENZIMAS ATIVAS SOBRE \\ CARBOIDRATOS DE Lentinus crinitus
}

\section{Renan Alberto MARIM ${ }^{1}$; Katielle Vieira AVELINO ${ }^{2}$; Marisangela Isabel Wietzikoski HALABURA ${ }^{3}$; Nelma Lopes ARAÚJO' ${ }^{4}$; Thiago Teodoro SANTANA ${ }^{5}$; Giani Andrea LINDE ${ }^{6}$; Nelson Barros COLAUTO ${ }^{7}$; Juliana Silveira do VALLE ${ }^{8}$}

1. Doutorando em Biotecnologia Aplicada à Agricultura - Universidade Paranaense - UNIPAR, Umuarama, PR. Bolsista CAPES; 2. Doutoranda em Biotecnologia Aplicada à Agricultura - Universidade Paranaense - UNIPAR, Umuarama, PR. Bolsista CAPES; 3. Mestranda em Biotecnologia Aplicada à Agricultura - Universidade Paranaense - UNIPAR, Umuarama, PR. Bolsista CAPES; 4. Doutoranda em Biotecnologia Aplicada à Agricultura - Universidade Paranaense - UNIPAR e Instituto Federal do Paraná - IFPR, Umuarama, PR; 5. Doutorando em Biotecnologia Aplicada à Agricultura - Universidade Paranaense - UNIPAR, Umuarama, PR. Bolsista CAPES; 6. Professora, Doutora, Biotecnologia Aplicada à Agricultura - Universidade Paranaense - UNIPAR; 7. Professor, Doutor, Biotecnologia Aplicada à Agricultura - Universidade Paranaense - UNIPAR; 8. Professora, Doutora, Biotecnologia Aplicada à Agricultura - Universidade Paranaense - UNIPAR. jsvalle@prof.unipar.br

\begin{abstract}
Fungi are capable of sensing light from ultraviolet to far-red and they use light as a source of information about the environment anticipating stress and adverse conditions. Lentinus crinitus is a lignin-degrading fungus which produces laccase and other enzymes of biotechnological interest. The effect of blue light on fungal enzymatic activity has been studied; however, it has not been found studies on the effect of the blue light on carbohydrate-active enzymes and on mycelial biomass production of L. crinitus. We aimed to investigate carbohydrate-active enzymes activity and mycelial biomass production of $L$. crinitus cultivated under continuous illumination with blue light. L. crinitus was cultivated in malt extract medium in the dark, without agitation, and under continuous illumination with blue light-emitting diodes. The blue light reduced the total cellulase, pectinase and xylanase activities but increased the endoglucanase activity. Blue light reduced the mycelial growth of $L$. crinitus in $26 \%$ and the enzymatic activity-to-mycelial biomass ratio ( $\mathrm{U} \mathrm{mg}^{-1} \mathrm{dry}_{\text {basis})}$ increased in $10 \%$ total cellulase, $33 \%$ endoglucanase, and $16 \%$ pectinase activities. Also, it is suggested that $L$. crinitus has a photosensory system and it could lead to new process of obtaining enzymes of biotechnological interest.
\end{abstract}

KEYWORDS: Cellulase. Hemicellulase. Lentinus crinitus. Polygalacturonase. Visible light wavelengths. White-rot fungi.

\section{INTRODUCTION}

All lifeforms are capable to obtain and decode information in their environment. Light is an abiotic environmental factor that regulates essential processes in several organisms including fungi (CASAS-FLORES; HERRERA-ESTRELLA, 2016). Fungi use light as information about the environment being also capable of sensing light from ultraviolet to far-red light (TISCH; SCHMOLL, 2010). Light might affect physiological responses of a fungus such as growth and growth direction, asexual and sexual reproduction, pigmentation, the circadian clock, secondary metabolism among others (IDNURM; HEITMAN, 2005). Fungi have photoresponse systems where specific photo sensory receptors respond to different light wavelengths (GLUKHOVA et al., 2014). The main ones are those photoreceptors that contain the chromophores flavin, retinal, and tetrapyrrole (FISCHER et al., 2016). Long-term light effects are related to great changes of fungal gene expression pattern, but it is still not clear how the coordinated activation and repression of several genes occur (FISCHER et al., 2016).

The blue-light response has been studied, notably in the fungal model of Neurospora crassa. The mechanisms of fungal blue light phototransduction require the $w c-1$ and $w c-2$ genes, named after the presence of a white collar (WC) of non-pigmented hyphae in mutant strains (RODRIGUEZ-ROMERO et al., 2010). Upon blue light exposure, the proteins $\mathrm{WC}-1$ and $\mathrm{WC}-2$ interact and form the white collar complex (WCC). WC-1 has a flavin-binding domain, protein-protein interaction domains (Per-Arnt-Sim) to interact with WC-2 to form WCC, and GATA-type zinc finger DNA binding domains also present in WC-2. Thus, 
WCC operates as a photoreceptor and a transcription factor that binds with light-response elements from the promoters of light-regulated genes affecting their expression (CORROCHANO, 2007; FULLER; LOROS; DUNLAP, 2015). Blue light response is conserved among fungi and WCC has orthologs found in Ascomycota, Basidiomycota, and Mucoromycotina (SCHMOLL, 2018).

The effect of light on the fungal enzyme activity has been studied such as cellullase from Neurospora crassa (SCHMOLL et al., 2012), lignin peroxidase from Phanerochaete chrysosporium (RAMÍREZ et al., 2010), laccase and cellobiose dehydrogenase from Cerrena unicolor, Phlebia lindnteri, and Pycnoporus sanguineus (HERNÁNDEZ et al., 2016; JANUSZ et al., 2016), and carbohydrate-active enzymes from Pleurotus eryngii (XIE et al., 2018) with varied responses of fungi to light, indicating that more explanations are needed on light-perception mechanisms and signal transduction in these microorganisms.

Carbohydrate-active enzymes (CAZymes) are involved in breakdown, biosynthesis, or modification of glycoconjugates, oligo- and polysaccharides and, CAZymes known as cell wall degrading enzymes, are directly involved in the hydrolysis of polysaccharides of the plant cell wall (ZHAO et al., 2013). This group of enzymes have become relevant mainly due to the fact that lignocellulosic biomass is an emerging source of fuels and chemicals, and because its depolymerization is usually required before it can be used in biotechnological applications (LÓPEZ et al., 2018).

The plant cell wall is organized as a structure of cellulose microfibrils embedded in a matrix made of hemicellulose, pectin, lignin, and proteins (SORIEUL et al., 2016). White-rot fungi are capable to degrade all the components of cell wall because they express an enzymatic system with different CAZymes and oxidoreductases (MALI et al., 2017). The cellulase complex contains enzymes that act synergically on the depolymerization of cellulose to glucose as endo-1,4- $\beta$-D-glucanases (EC 3.2.1.4), exo-1,4- $\beta$-D-glucanases (EC 3.2.1.91), and $\beta$-glucosidases (EC 3.2.1.21) (SINGHANIA et al., 2010). Because of the structure and variable organization of hemicellulose, its complete degradation depends on the action of a hydrolase consortium that includes endo-1,4- $\beta$-xylanase (EC 3.2.1.8), exo-1,4- $\beta$-xylosidases (EC 3.2.1.37), $\alpha$-Larabinofuronosidase (EC 3.2.1.55), endo- $\alpha-1,5-$ arabnananse (EC 3.2.1.99), endo- $\beta$-1,4-mannanases (EC 3.2.1.78), exo- $\beta$-1,4-mannosidase (EC 3.2.1.25), $\alpha$-glucoronidases (EC 3.2.1.139), and hemicellulolytic esterases as acetyl xylan esterase (EC 3.1.1.72) and acetyl mannan esterase (EC 3.1.1.6) (SHALLOM; SHOHAM, 2003). Pectin hydrolysis by fungi also occurs by the activity of several pectinolytic enzymes classified according to their catalytic reaction as polygalacturonases, pectin esterases, and pectin lyases (JAYANI; SAXENA; GUPTA, 2005). Polygalacturonase (1-4- $\alpha-D-$ galacturonan glycanohydrolase, EC 3.2.1.15) degrade the polygalacturonic acid chain by randomly cleaving 1,4- $\alpha$-glycosidic bonds between two galacturonic acid residues releasing monosaccharide or oligogalacturonides (SUNNOTEL; NIGAM, 2002).

Lentinus crinitus (L.) Fr. (Basidiomycota) is a white-rot fungus with pantropical occurrence that grows in decaying wood (SILVA; GIBERTONI, 2006). It is known to produce enzymes of biotechnological interest such as laccase (VALLE et al., 2014; SANTANA et al., 2018), cellulase, and xylanase (CAMBRI et al., 2016) under different cultivation systems (MARIM et al., 2018). Its ability to decolorize dyes (ALMEIDA et al., 2018) and produce antioxidant compounds (UMEO et al., 2015) was also reported. However, there is a lack of studies on the effect of light on the enzymatic activity or any metabolism aspect of this fungus. In our study, we investigated how the activity of carbohydrate-active enzymes and the mycelial biomass growth of L. crinitus are affected by blue light. The understanding of how light affects $L$. crinitus contributes to increase the knowledge of light impact and regulation to this fungus, aiming the potential development of biotechnological applications and/or optimization processes for enzyme production.

\section{MATERIAL AND METHODS}

\section{Microorganism and inoculum}

Lentinus crinitus (L.) Fr. (Polyporaceae) strain U9-1 from the culture collection of the Graduate Program in Biotechnology Applied to Agriculture of the Paranaense University was used in the assays. The GenBank accession number of the internal transcribed spacer (ITS) of ribosomal DNA sequence is MG211674 (MARIM et al., 2018).

The mycelial biomass was cultivated on 20 $\mathrm{g} \mathrm{L}^{-1}$ malt extract agar (MEA; Himedia ${ }^{\circledR}$ ) medium at $28 \pm 1{ }^{\circ} \mathrm{C}$ in the dark. Three MEA disks $(6 \mathrm{~mm}$ diameter) with mycelia without sectoring were used as inoculum (VALLE et al., 2014). 


\section{Mycelial biomass growth and enzymatic activity under blue light}

Fungal cultivation to obtain enzymatic activity and mycelial biomass yield was in conical flasks $(250 \mathrm{~mL})$ with $100 \mathrm{~mL}$ of autoclaved $\left(121^{\circ} \mathrm{C}\right.$ for $20 \mathrm{~min}$ ) malt extract (ME, $20 \mathrm{~g} \mathrm{~L}^{-1}$, Himedia ${ }^{\circledR}$ ) medium. After inoculation, the flasks with $\mathrm{ME}$ liquid medium were kept at $28 \pm 1{ }^{\circ} \mathrm{C}$ for 15 days without agitation. Biomass yield was done under continuous blue light wavelength (450-495 nm) using light-emitting diodes (LED). The LED intensity was set at $20 \mu \mathrm{mol} \mathrm{m} \mathrm{m}^{-2} \mathrm{~s}^{-1}$. Cultivation in the dark was used as control and the flasks were covered to prevent any light exposition. After 15 days with or without blue light, mycelial biomass was separated from the cultivation medium with a filter (Whatman ${ }^{\circledR}$ grade 1) by vacuum filtration, washed, and dried at $60{ }^{\circ} \mathrm{C}$ until constant mass, and the filtered cultivation medium was used for enzymatic activities.

\section{Cellulase assay}

The total cellulolytic activity and endoglucanase activity were determined according to Ghose (1987). Total cellulase (FPase) activity was determined with filter paper $(1 \mathrm{x} 6 \mathrm{~cm} ; 50 \mathrm{mg}$; Whatman $^{\circledR}$ grade 1) strips as substrate. The enzymatic reaction mixture contained one filter paper strip, $500 \mu \mathrm{L}$ sodium citrate buffer $(0.05 \mathrm{M}$, $\mathrm{pH}$ 4.8), and $250 \mu \mathrm{L}$ ME. The mixture was incubated for $60 \mathrm{~min}$ at $50{ }^{\circ} \mathrm{C}$ and the release of reducing groups from filter paper was determined with 3,5-dinitrosalicylic acid (DNS) reagent assay (MILLER, 1959). FPase activity was expressed in international units (U) and was defined as the amount of enzyme required to release $1 \mu \mathrm{mol}$ of glucose per minute.

Endoglucanase (CMCase) activity was determined with $2 \%$ carboxymethyl cellulose (CMC; mass/volume) in $0.05 \mathrm{M}$ sodium citrate buffer ( $\mathrm{pH} 4.8)$ as substrate. The enzymatic reaction was set mixing $250 \mu \mathrm{L} \mathrm{CMC}$ and $250 \mu \mathrm{L} \mathrm{ME}$. The mixture was incubated for $30 \mathrm{~min}$ at $50{ }^{\circ} \mathrm{C}$ and the release of reducing groups from filter paper was determined with DNS reagent assay (MILLER, 1959). CMCase activity was expressed in international units (U) and was defined as the amount of enzyme required to release $1 \mu \mathrm{mol}$ of glucose per minute.

\section{Pectinase assay}

Pectinase (polygalacturonase) activity was determined with citric pectin as substrate (BIZ et al., 2016). A reaction mixture was assembled containing $250 \mu \mathrm{L}$ citric pectin (1\% mass/volume) in sodium acetate buffer ( $0.2 \mathrm{M}, \mathrm{pH} 4.5)$ and $250 \mu \mathrm{L} \mathrm{ME}$. The mixture was incubated for $20 \mathrm{~min}$ at $30{ }^{\circ} \mathrm{C}$ and the release of reducing groups from pectin was determined with DNS reagent assay (MILLER, 1959). Pectinase activity was expressed in international units (U) and was defined as the amount of enzyme required to release $1 \mu \mathrm{mol}$ of Dgalacturonic acid per minute.

\section{Xylanase assay}

Xylanase activity was determined using $1 \%$ xylan from birchwood (mass/volume) in sodium citrate buffer $(0.05 \mathrm{M}, \mathrm{pH}$ 5.3) as substrate (BAILEY; BIELY; POUTANEN, 1992). The xylan solution $(900 \mu \mathrm{L})$ was mixed with $100 \mu \mathrm{L} \mathrm{ME}$, incubated for $5 \mathrm{~min}$ at $50{ }^{\circ} \mathrm{C}$ and the release of reducing groups from xylan was determined with DNS reagent assay (MILLER, 1959). Xylanase activity was expressed in international units (U) and was defined as the amount of enzyme required to release $1 \mu \mathrm{mol}$ of xylose per minute.

\section{Statistical analysis}

The assays had a completely random design with three replications. The results were evaluated using Student's unpaired t-test and significant differences among arithmetic means and standard deviation were determined at $5 \%$ probability.

\section{RESULTS AND DISCUSSION}

The cultivation under blue light reduced the total cellulase activity in $15 \%$, pectinase in $8 \%$, and xylanase in $33 \%$, but increased endoglucanase activity in $13 \%$ compared to the cultivation in the dark (Table 1). The decrease of mycelial biomass growth of $L$. crinitus cultivated under blue light was $26 \%$ compared to the cultivation in the dark (Table 1). However, enzymatic activity-to-mycelial biomass ratio was greater under blue light with the increase in $33 \%$ endoglucanase activity, and $16 \%$ pectinase compared to the production in the dark, except for total cellulase and xylanase activities which were the same for the cultivation under light or in the dark.

Specific light wavelengths may affect growth, secondary metabolism and metabolite production in fungi (IDNURM; HEITMAN, 2005). Most of other reports on the effect of light are on the metabolism of ascomycetes and there are fewer studies on basidiomycetes (JANUSZ et al., 2016). In addition, more relevant studies that approach the effects of light on the enzymatic expression were carried out with the genus Trichoderma (SCHMOLL, 2018). Our study is the first report 
about the effect of blue light on L. crinitus mycelial biomass production and enzymatic activity.

Table 1. Enzymatic activity, mycelial biomass (average \pm standard deviation), and enzymatic activity-tomycelial biomass ratio of Lentinus crinitus cultivated in malt extract liquid medium $\left(20 \mathrm{~g} \mathrm{~L}^{-1}\right)$, static, under blue light or in the dark, for 15 days.

\begin{tabular}{|c|c|c|c|c|c|c|}
\hline \multirow[t]{2}{*}{$\begin{array}{l}\text { Enzymatic activity or } \\
\text { Mycelial biomass }\end{array}$} & \multicolumn{3}{|c|}{$\begin{array}{c}\text { Enzymatic activity } \\
\qquad\left(\mathrm{U} \mathrm{mL}^{-1}\right)\end{array}$} & \multicolumn{3}{|c|}{$\begin{array}{c}\text { Enzymatic activity-to-Mycelial } \\
\text { biomass ratio } \\
\left(\mathrm{U} \mathrm{mg}^{-1} \text { dry basis }\right)\end{array}$} \\
\hline & in the dark & in blue light & $\begin{array}{c}p \\
\text { value }\end{array}$ & in the dark & in blue light & $\begin{array}{c}p \\
\text { value }\end{array}$ \\
\hline Total cellulase (FPase) & $2.0 \pm 0.01^{\mathrm{a}}$ & $1.7 \pm 0.1^{b}$ & 0.029 & $0.9 \pm 0.0^{\mathrm{a}}$ & $1.0 \pm 0.05^{\mathrm{a}}$ & 0.156 \\
\hline Endoglucanase (CMCase) & $2.3 \pm 0.08^{\mathrm{b}}$ & $2.6 \pm 0.1^{\mathrm{a}}$ & 0.046 & $1.0 \pm 0.1^{\mathrm{b}}$ & $1.5 \pm 0.05^{\mathrm{a}}$ & 0.010 \\
\hline Pectinase & $11.5 \pm 0.2^{\mathrm{a}}$ & $10.6 \pm 0.3^{b}$ & 0.019 & $5.1 \pm 0.1^{\mathrm{b}}$ & $6.1 \pm 0.2^{\mathrm{a}}$ & 0.062 \\
\hline Xylanase & $8.7 \pm 0.5^{\mathrm{a}}$ & $5.8 \pm 0.7^{\mathrm{b}}$ & 0.025 & $3.8 \pm 0.2^{\mathrm{a}}$ & $3.3 \pm 0.4^{\mathrm{a}}$ & 0.427 \\
\hline Mycelial biomass (mg mL $\mathrm{mL}^{-1}$ ) & $2.3 \pm 0.1^{\mathrm{a}}$ & $1.7 \pm 0.1^{\mathrm{b}}$ & 0.019 & -- & -- & \\
\hline
\end{tabular}

Different letter on the same line indicate significant difference between the cultivation in the dark and under blue light according to Student's t-test $(p \leq 0.05)$.

Cultivation of $L$. crinitus under blue light increased endoglucanase activity and reduced activity of other evaluated CAZymes in the enzymatic extract. On the other hand, the enzymatic activity related to mycelial biomass was greater for endoglucanase and pectinase, and for xylanase and total cellulase the activity was the same as for the one in the dark. This suggests that there was a greater cellulolytic and pectinolytic activity of the mycelium when L. crinitus was cultivated under blue light, probably due to modifications of the metabolism and/or increase in enzymes expression. In addition, considering that the mycelium grew less under blue light, it is evident that a higher enzymatic activity was produced by a less developed mycelium. Although gene expression analyzes have not been conducted, literature data and our results support the assumption that blue light can modify CAZymes expression of L. crinitus. Xie et al. (2018) that investigated the gene expression of carbohydrate-active enzymes on primordium differentiation into fruiting body of Pleurotus eryngii after blue light exposition observed that 319 carbohydrate-active enzymes were differentially expressed and endoglucanase, exoglucanase, betaglucosidase, and pectin lyase had their expression and enzymatic activity increased.

These results suggest that the activity and expression of $L$. crinitus CAZymes may be affected by a photosystem similar to $N$. crassa WC photosystem. WC system of response to blue light encompasses mainly two genes (wc-1 and wc-2), whose products get linked to promoters of lightregulated genes and act as a transcription factor complex activated in response to blue light (TISCH; SCHMOLL, 2010). Although there are not data on
L. crinitus genome yet, the genome analysis of other fungi indicates the presence of homologous sequences to $\mathrm{WC}$ system in enzyme expression regulating regions. Sano et al. (2009) identified an equivalent of $w c-2$ gene in cDNA of Lentinula edodes (phrB) and a deduced PHRB protein contained DNA binding consensus sequence complementary to the light responsive elements (LRE) found in a tyrosinase gene promoter. GyalaiKorpos et al. (2010) screened gene promoters that codify enzymes involved in plant cell wall degradation of Trichoderma reesei when searching for LRE and found at least one LRE in promoters from 7 genes that codify endoglucanases and from four genes that codify xylanases. This suggests that L. crinitus may have a system of CAZyme regulation, mainly due to the effect of blue light on the activity of these enzymes.

As mentioned before, blue light significantly reduced mycelium biomass growth of L. crinitus in liquid cultivation. This species is a robust fungus that can grow over a wide range of substrates (ALMEIDA et al., 2018), temperatures and $\mathrm{pH}$ of the cultivation media (MARIM et al., 2018), however, blue light negatively influenced the biomass yield. Our results are similar to the one reported by Nakano et al. (2010) who cultivated Pleurotus ostreatus in Petri dishes under blue light with suppression of mycelial biomass growth according to light intensity. Ramírez et al. (2010) reported that the cultivation of Phanerochaete chrysosporium in liquid medium and under different LED affected mycelial biomass production with decrease of $3.5 \%$ under blue light. On the other hand, Zapata et al. (2009) cultivated Ganoderma lucidum in liquid medium under continuous lighting 
with different wavelengths, and observed that the blue light increased mycelial biomass production in $23 \%$. The available data in the literature on the effects of light on the vegetative growth of basidiomycete mycelial biomass demonstrate that the responses to light are complex and depend on each fungus, but for the majority the response to light involves the integration of multiple light inputs by photosensitive proteins (FULLER; LOROS; DUNLAP, 2015). Light properties such as wavelength, intensity, dose of irradiation can vary widely which makes it difficult to compare results and the fungal sensitivity to it and throughout different fungal development stages (POYEDINOK et al., 2008).

The fungal metabolic responses to light conditions in the environment have an ecological role that allows the fungal adaptation to stressful or adverse conditions. Thus, it is important to explore and know aspects of L. crinitus physiology under varied conditions of luminosity in order to develop cultivation strategies, aiming the production of mycelial biomass and specific enzymes.

\section{CONCLUSIONS}

Blue light on L. crinitus cultivation reduces the mycelial biomass growth but increases the enzymatic activity-to-mycelial biomass ratio of endoglucanase and pectinase when compared to the cultivation condition in darkness.

The enzymatic activity-to-mycelial biomass ratio is the same for total cellulase and xylanase when compared to the cultivation condition in darkness.

\section{ACKNOWLEDGMENTS}

The authors thank Universidade Paranaense, Graduate Program of Biotechnology Applied to Agriculture, Fundação Araucária, Coordenação de Aperfeiçoamento de Pessoal de Nível Superior (CAPES) - Brazil -finance code 001-, and the Conselho Nacional de Desenvolvimento Científico e Tecnológico (CNPq, 307953/2017-3) for the financial support and fellowship.

RESUMO: Fungos são capazes de sentir a luz com comprimentos de onda que variam do ultravioleta ao infravermelho e usam a luz como fonte de informação sobre o ambiente, antecipando condições adversas e de estresse. Lentinus crinitus é um fungo ligninolítico que produz lacase e outras enzimas de interesse biotecnológico. O efeito da luz azul na atividade enzimática de fungos já foi estudado, contudo, ainda não há estudos sobre o efeito da luz azul na produção de enzimas ativas sobre carboidratos (CAZymes, carbohydrateactive enzymes) e de biomassa micelial de L. crinitus. O objetivo deste estudo foi investigar a avitivade de CAZymes e a produção de biomassa micelial de $L$. crinitus cultivado sob iluminação continua com luz azul. $L$. crinitus foi cultivado em meio extrato de malte, sem agitação, na ausência de luz e sob luz continua fornecida por diodos emissores de luz azul. A luz azul reduziu a atividade de cellulase total, pectinase e xilanase, mas aumentou a atividade de endoglucanase. A luz azul reduziu o crescimento micelial de L. crinitus em $26 \%$ e aumentou a razão atividade enzimática/biomassa micelial ( $\mathrm{U} \mathrm{mg} \mathrm{m}^{-1} \mathrm{em}$ base seca) de cellulase total em $10 \%$, endoglucanase em 33\% e pectinase em 16\%. Além disso, sugere-se que L. crinitus possua um sistema fotossensorial que poderia ser explorado para a otimização de bioprocessos que visam a obtenção de enzimas de interesse biotecnológico.

PALAVRAS-CHAVE: Celulase. Hemicelulase. Lentinus crinitus. Poligalacturonase. Luz visível. Fungo da podridão branca.

\section{REFERENCES}

ALMEIDA, P. H., OLIVEIRA, A. C. C. D., SOUZA, G. P. D., FRIEDRICH, J. C., LINDE, G. A., COLAUTO, N. B., VALLE, J. S. D. Decolorization of remazol brilliant blue R with laccase from Lentinus crinitus grown in agro-industrial by-products. An. Acad. Bras. Cienc., v. 90, p. 3463-3473, 2018. https://doi.org/10.1590/00013765201820170458

BAILEY, M. J., BIELY, P., POUTANEN, K. Interlaboratory testing of methods for assay of xylanase activity. J. Biotechnol., v. 23, p. 257-270, 1992. https://doi.org/10.1016/0168-1656(92)90074-j 
BIZ, A., FINKLER, A. T. J., PITOL, L. O., MEDINA, B. S., KRIEGER, N., MITCHELL, D. A. Production of pectinases by solid-state fermentation of a mixture of citrus waste and sugarcane bagasse in a pilot-scale packed-bed bioreactor. Biochem. Eng. J., v. 111, p. 54-62, 2016. https://doi.org/10.1016/j.bej.2016.03.007

CAMBRI, G., SOUSA, M. M. L. D., FONSECA, D. D. M., MARCHINI, F. K., SILVEIRA, J. L. M. D., PABA, J. Analysis of the biotechnological potential of a Lentinus crinitus isolate in the light of its secretome. J. Proteome Res., v. 15, p. 4557-4568, 2016. https://doi.org/10.1021/acs.jproteome.6b00636

CASAS-FLORES, S., HERRERA-ESTRELLA, A. The bright and dark sides of fungal life. In: DRUZHININA, I., KUBICEK, C (Ed.). Environmental and microbial relationships. The Mycota (A Comprehensive Treatise on Fungi as Experimental Systems for Basic and Applied Research) vol IV. Vienna: Springer, 2016. p. 41-77. https://doi.org/10.1007/978-3-319-29532-9_3

CORROCHANO, L. M. Fungal photoreceptors: sensory molecules for fungal development and behavior. Photochem. Photobiol. Sci., v. 6, p. 725-736, 2007. https://doi.org/10.1039/b702155k

FISCHER, R., AGUIRRE, J., HERRERA-ESTRELLA, A., CORROCHANO, L. M. The complexity of fungal vision, Microbiol. Spectrum, v. 4, FUNK-0020-2016, 2016. https://doi.org/10.1128/microbiolspec.funk-00202016

FULLER, K. K., LOROS, J. J., DUNLAP, J. C. Fungal photobiology: visible light as a signal for stress, space and time. Curr. Genet., v. 61, p. 275-288, 2015. https://doi.org/10.1007/s00294-014-0451-0

GHOSE, T. K. Measurement of cellulase activities. Pure Appl. Chem., v. 59, p. 257-268, 1987. https://doi.org/10.1351/pac198759020257

GLUKHOVA, L. B., SOKOLYANSKAYA, L. O., PLOTNIKOV, E. V., GERASIMCHUK, A. L., KARNACHUK, O. V., SOLIOZ, M., KARNACHUK, R. A. Increased mycelial biomass production by Lentinula edodes intermittently illuminated by green light emitting diodes. Biotechnol. Lett., v. 36, p. 22832289, 2014. https://doi.org/10.1007/s10529-014-1605-3

GYALAI-KORPOS, M., NAGY, G., MARECZKY, Z., SCHUSTER, A., RÉCZEY, K., SCHMOLL, M. Relevance of the light signaling machinery for cellulase expression in Trichoderma reesei (Hypocrea jecorina). BMC Res. Notes, v. 3, p. 330, 2010. https://doi.org/10.1186/1756-0500-3-330

HERNÁNDEZ, C., SILVA, A.-M. F. D., ZIARELLI, F., PERRAUD-GAIME, I., GUTIÉRREZ-RIVERA, B., GARCÍA-PÉREZ, J.A., ALARCÓN, E. Laccase induction by synthetic dyes in Pycnoporus sanguineus and their possible use for sugar cane bagasse delignification. Appl. Microbiol. Biot., v. 101, p. 1189-1201, 2016. https://doi.org/10.1007/s00253-016-7890-0

IDNURM, A., HEITMAN, J. Light controls growth and development via a conserved pathway in the fungal kingdom. PLoS Biol., v. 3, p. e95, 2005. https://doi.org/10.1371/journal.pbio.0030095

JANUSZ, G., SULEJ, J., JASZEK, M., OSIŃSKA-JAROSZUK, M. Effect of different wavelengths of light on laccase, cellobiose dehydrogenase, and proteases produced by Cerrena unicolor, Pycnoporus sanguineus and Phlebia lindtneri. Acta Biochim. Pol., v. 63, p. 2015-1235, 2016. https://doi.org/10.18388/abp.2015_1235

JAYANI, R. S., SAXENA, S., GUPTA, R. Microbial pectinolytic enzymes: A review. Process Biochem., v. 40, p. 2931-2944, 2005. https://doi.org/10.1016/j.procbio.2005.03.026

LÓPEZ, S. C., PENG, M., ISSAK, T. Y., DALY, P., VRIES, R. P. D., MÄKELÄ, M. R. Induction of genes encoding plant cell wall-degrading carbohydrate-active enzymes by lignocellulose-derived monosaccharides and cellobiose in the white-rot fungus Dichomitus squalens. Appl. Environ. Microb., v. 84, p. e00403-18, 2018. https://doi.org/10.1128/aem.00403-18 
MALI, T., KUUSKERI, J., SHAH, F., LUNDELL, T. K. Interactions affect hyphal growth and enzyme profiles in combinations of coniferous wood-decaying fungi of Agaricomycetes. Plos One, v. 12, e0185171, 2017. https://doi.org/10.1371/journal.pone.0185171

MARIM, R. A., AVELINO, K. V., LINDE, G. A., COLAUTO, N. B., VALLE, J. S. Lentinus crinitus strains respond differently to cultivation $\mathrm{pH}$ and temperature. Genet. Mol. Res., v. 17, gmr16039885, 2018. https://doi.org/10.4238/gmr16039885

MILLER, G. L. Use of dinitrosalicylic acid reagent for determination of reducing sugar. Anal. Chem., v. 31, p. 426-428, 1959. https://doi.org/10.1021/ac60147a030

POYEDINOK, N. L., MYKHAILOVA, O. B., SHCHERBA, V. V., BUCHALO, A. S., NEGRIYKO, A. M. Light regulation of growth and biosynthetic activity of Ling Zhi or Reishi medicinal mushroom, Ganoderma lucidum (W. Curt.: Fr.) P. Karst. (Aphyllophoromycetideae), in pure culture. Int. J. Med. Mushrooms, v. 10, p. 369-378, 2008. https://doi.org/10.1615/intjmedmushr.v10.i4.100

RAMÍREZ, D. A., MUÑOZ, S. V., ATEHORTUA, L., MICHEL, F. C. Effects of different wavelengths of light on lignin peroxidase production by the white-rot fungi Phanerochaete chrysosporium grown in submerged cultures. Bioresource Technol., v. 101, p. 9213-9220, 2010. https://doi.org/10.1016/j.biortech.2010.06.114

RODRIGUEZ-ROMERO, J., HEDTKE, M., KASTNER, C., MÜLLER, S., FISCHER, R. Fungi, hidden in soil or up in the air: Light makes a difference. Annu. Rev. Microbiol., v. 64, p. 585-610, 2010.

https://doi.org/10.1146/annurev.micro.112408.134000

SANO, H., KANEKO, S., SAKAMOTO, Y., SATO, T., SHISHIDO, K. The basidiomycetous mushroom Lentinula edodes white collar-2 homolog PHRB, a partner of putative blue-light photoreceptor PHRA, binds to a specific site in the promoter region of the L. edodes tyrosinase gene. Fungal Genet. Biol., v. 46, p. 333-341, 2009. https://doi.org/10.1016/j.fgb.2009.01.001

SANTANA, T. T., LINDE, G. A., COLAUTO, N. B., VALLE, J. S. Metallic-aromatic compounds synergistically induce Lentinus crinitus laccase production. Biocatal. Agric. Biotechnol., v. 16, p. 625-630, 2018. https://doi.org/10.1016/j.bcab.2018.10.018

SCHMOLL, M., TIAN, C., SUN, J., TISCH, D., GLASS, N. L. Unravelling the molecular basis for light modulated cellulase gene expression - the role of photoreceptors in Neurospora crassa. BMC Genomics, v. 13, p. 127, 2012. https://doi.org/10.1186/1471-2164-13-127

SCHMOLL, M. Light, stress, sex and carbon - The photoreceptor ENVOY as a central checkpoint in the physiology of Trichoderma reesei. Fungal Biol-UK, v. 122, p. 479-486, 2018.

https://doi.org/10.1016/j.funbio.2017.10.007

SHALLOM, D., SHOHAM, Y. Microbial hemicellulases. Curr. Opin. Microbiol., v. 6, p. 219-228, 2003. https://doi.org/10.1016/s1369-5274(03)00056-0

SILVA, G. T., GIBERTONI, T. B. Aphyllophorales (Basidiomycota) em áreas urbanas da Região Metropolitana do Recife, PE, Brasil. Hoehnea, v. 33, p. 533-543, 2006.

SINGHANIA, R. R., SUKUMARAN, R. K., PATEL, A. K., LARROCHE, C., PANDEY, A. Advancement and comparative profiles in the production technologies using solid-state and submerged fermentation for microbial cellulases. Enzyme Microb. Tech., v. 46, p. 541-549, 2010.

https://doi.org/10.1016/j.enzmictec.2010.03.010

SORIEUL, M., DICKSON, A., HILL, S., PEARSON, H. Plant fibre: Molecular structure and biomechanical properties, of a complex living material, influencing its deconstruction towards a biobased composite.

Materials, v. 9, p. 618, 2016. https://doi.org/10.3390/ma9080618 
SUNNOTEL, O., NIGAM, P. Pectinolytic activity of bacteria isolated from soil and two fungal strains during submerged fermentation. World J. Microb. Biot., v. 18, p. 835-839, 2002.

https://doi.org/10.1023/a:1021209123641

TISCH, D., SCHMOLL, M. Light regulation of metabolic pathways in fungi. Appl. Microbiol. Biot., v. 85, p. 1259-1277, 2010. https://doi.org/10.1007/s00253-009-2320-1

UMEO, S., SOUZA, G., RAPACHI, P., GARCIA, D., PACCOLA-MEIRELLES, L., VALLE, J., COLAUTO, N., LINDE, G. Screening of basidiomycetes in submerged cultivation based on antioxidant activity. Genet.

Mol. Res., v. 14, p. 9907-9914, 2015. https://doi.org/10.4238/2015.august.19.25

VALLE, J., VANDENBERGHE, L., SANTANA, T., ALMEIDA, P., PEREIRA, A., LINDE, G., COLAUTO, N., SOCCOL, C. Optimum conditions for inducing laccase production in Lentinus crinitus. Genet. Mol. Res., v. 13, p. 8544-8551, 2014. https://doi.org/10.4238/2014.october.20.31

XIE, C., GONG, W., ZHU, Z., YAN, L., HU, Z., PENG, Y. Comparative transcriptomics of Pleurotus eryngii reveals blue-light regulation of carbohydrate-active enzymes (CAZymes) expression at primordium differentiated into fruiting body stage. Genomics, v. 110, p. 201-209, 2018.

https://doi.org/10.1016/j.ygeno.2017.09.012

ZAPATA, P. A., ROJAS, D. F., RAMIREZ, D. A., FERNANDEZ, C., ATEHORTUA, L. Effect of different light-emitting diodes on mycelial biomass production of Ling Zhi or Reishi medicinal mushroom Ganoderma lucidum (W. Curt.: Fr.) P. Karst. (Aphyllophoromycetideae). Int. J. Med. Mushrooms, v. 11, p. 93-99, 2009. https://doi.org/10.1615/intjmedmushr.v11.i1.110

ZHAO, Z., LIU, H., WANG, C., XU, J.-R. Comparative analysis of fungal genomes reveals different plant cell wall degrading capacity in fungi. BMC Genomics, v. 14, p. 274, 2013. https://doi.org/10.1186/1471-2164-14274 